\title{
The Benefits of School-Based Assessment
}

\author{
Azlin Norhaini Mansor ${ }^{1}$, Ong Hee Leng ${ }^{2}$, Mohamad Sattar Rasul ${ }^{1}$, Rose Amnah Raof ${ }^{3}$ \& Nurhayati Yusoff ${ }^{4}$ \\ ${ }^{1}$ Universiti Kebangsaan Malaysia, Bangi, Malaysia \\ ${ }^{2}$ Open University Malaysia, Kuala Lumpur, Malaysia \\ ${ }^{3}$ Universiti Malaya, Kuala Lumpur, Malaysia \\ ${ }^{4}$ Multi Media University, Malacca, Malaysia \\ Correspondence: Azlin Norhaini Mansor, Faculty of Education, Universiti Kebangsaan Malaysia, Bangi, \\ Selangor, Malaysia. E-mail: azlinmansor@ukm.my
}

Received: February 17, 2013 Accepted: March 29, 2013 Online Published: April 25, 2013

doi:10.5539/ass.v9n8p101 URL: http://dx.doi.org/10.5539/ass.v9n8p101

\begin{abstract}
School-based assessment (SBA) approach in evaluating students' academic progress was officially introduced by the Ministry of Education Malaysia and implemented in-line with the Standards-based Primary School Curriculum, in stages starting in 2011 as part of Malaysia educational reform. Under this approach, teachers are given greater responsibility to design quality assessments that align with their students' learning outcomes Hence, the objectives of this qualitative case study is focused on how the newly introduced assessment approach has benefits the teaching and learning process in evaluating Year 1 academic progress in three urban Chinese primary schools. Data collected from interviews involving three Year 1 Chinese language teachers found that teachers have very positive perspectives towards SBA and that overall both teachers and students have benefited from this system. However, there are also weaknesses that need to be acknowledged and improvements to be made. The findings implicate that for SBA to be successful, teachers need to be creative, using varying strategies in their teaching and exploiting repertoire of methods in assessing their students. Further study on the matter is inevitable in ensuring the success of SBA's implementation.
\end{abstract}

Keywords: school-based assessment - SBA, benefits - case study

\section{Introduction}

To accomplish the government's initiatives in improving the quality of human capital development to suit the world's rapid changes, the Malaysian Examinations Syndicate (MES) has introduced the National Educational Assessment System (NEAS). The assessment system proposed by the MES promotes a change from a one-off certification system to one that propagates accumulative graduation. Therefore the school-based assessment (SBA) approach in evaluating students' academic progress was officially introduced by the Ministry of Education (MOE) and implemented in-line with the Standards-based Primary School Curriculum also known as KSSR, in stages starting in 2011 as part of Malaysia's educational reform.

Under this system, teachers are given greater responsibility to design quality assessments that align with the learning outcomes as they are the most suitable people to assess their students and they have a better understanding of the context of the subject area. This provides opportunities for teachers to continuously monitor their students and to give constructive feedback to improve students' learning abilities (Brown, 2001; AACU, 2011). Based on the assessment outcomes, teachers can make a further decision whether to continue to a new topic, give necessary help or send the more academically challenged students to remedial class. All students will be appraised based on their ability and readiness and teachers are encouraged to use various methods such as quizzes, question and answer sessions, short writing, dramas, and role-playing to assess students' learning outcomes (Davison, 2007; Dietel, Herman \& Knuth, 1991). Indirectly, teachers have to develop a series of effective teaching strategies to enhance the learning for students with different abilities (Mansor, 2012). This way, students are able to progress according to their ability, good students progressing faster and weaker students given more time to learn (Chapman, 2010).

With the implementation of school-based assessment, the MOE (2012) not only hopes to improve students' achievements in learning by raising their confidence, but also hopes to improve teachers' teaching strategies. 
Thus, the government acknowledges the challenges that may need to be overcome, including teachers' readiness, skills and their extra workload. As such, the government has been ready to provide further explanation and extra training programs to cater to these problems.

\subsection{Benefits of School-Based Assessment}

Assessment should be viewed as a tool to measure the effectiveness of teaching and learning process, and should not be interpreted as the objective of student's learning experiences (Yong \& Lim, 2008). It should serve as a mean to attain educational goals. MOE Malaysia believes that SBA has the characteristics that fulfill the above requirement. And it is the ideal assessment system to relieve students' pressure while at the same time allowing teacher initiative in assessing their students (Brown, 2001). To promote the benefits of the assessment, teachers are expected to be involved in four phases of the assessment process: a) planning, b) gathering evidence, c) interpreting evidence, and d) using the results for decision making.

The benefits laid down by the Hong Kong SBA Consultancy Team (2005) for using SBA in teaching a language subject such as English, includes providing stable and continuous pressure-free assessment, reducing the reliance on standardized examination, improving test item reliability, reflecting students' ability, promoting leisure reading, fostering teaching, enforcing independent learning, facilitating learning autonomy and empowering teachers in the evaluation process.

Another important benefit of SBA based on the researchers teaching experience is that students themselves are evaluated based on school standards and school information, not on statewide or nationwide information. Students are not compared to students in other locations when school-based evaluation is used. Though NEAS regulates that SBA encompasses only a percentage of the total evaluations used in schools, the bigger picture impact is how SBA itself transforms the classroom teaching and learning process that benefits the students most. Because SBA is completely educator written and can create evaluations based on their own students' accomplishments, it clearly shows what students have learned during a specific grading period or school year; unlike standardized tests, which are researched and written by the state or by teachers in another school.

In the case of Malaysia, students are given mid-year and end-year statewide tests for easy standardizations and school ranking practices. These tests assume that all schools study the same material covering similar topics. While this should be true, the fact is that some schools do not get to cover every topic due to unexpected situations or students' inability to complete a study in a particular area. School-based evaluations can be tailor made to include only what has been accomplished by the students and the scores will reflect what the students have actually learned, instead of what they were supposed to be learning.

All of the above suggest that the change in the assessment system has further lead to a paradigm change in the teaching and learning processes of all primary schools that deserve the attention of academicians, educators and researchers, including stakeholders. Therefore, the role of teachers in this new assessment system is vital; teachers have to have a variety of teaching approaches and assessment techniques that have a direct impact on the assessment outcomes (Chan, Sidhu, \& Yunus, 2006). The questions of whether SBA is suitable to our education system and what the teachers' perspectives are towards SBA has led to this study. More important is, what benefits would both teachers and students get from the implementation of SBA in evaluating academic performance?

\section{Objective}

The objective of this study is to identify the benefits in implementing SBA in a language-based subject, i.e. the Chinese language. It also aims to understand the rationale supporting these benefits for both teachers and students from the implementers' own perspectives.

\section{Methodology}

This is a small scale preliminary qualitative case study based on the observations and interviews of three experienced Year 1 Chinese language teachers at three different Chinese Primary School. The first is Mr. Chan, who has been teaching the subject for more than 20 years' in a small Chinese school in a rural area. Next is Ms. Tan, with 8 years teaching experience and Ms. Loh, with 10 years teaching experience, both of whom are teachers at two different Chinese schools in an urban area. All teachers attended a one-week course on SBA approach organized by the District Education Office and were selected purposively based on their excellent record as Chinese language teachers. All teachers were interviewed for a total of two hours each using a prepared semi-structured interview protocol. Interview data was transcribed and analyzed together with field-notes data from three classroom observations of each teacher. 


\section{Findings}

What is most important is that all the teachers involved in this study were very committed and have taken a positive approach to this latest policy on assessment. Classroom observations on all of the teachers proves further that these teachers take their jobs very seriously and go all out to make the teaching and learning process lively, interesting and to touch each student's learning cord. They all agreed that there were more 'teething troubles' than problems, and overall they managed to embrace the benefits of SBA amidst all of the challenges, which they had to overcome at the same time. This study found that for these Chinese language teachers, the benefits that outweighed the problems were that the implementation of SBA encourages personal progress, helps to develop positive attitudes, enhances collaborative skills and promotes creative teaching and learning activities.

\subsection{Encourages Personal Progress}

From the respondents' point of view, one of the benefits of SBA is that it encourages both the teacher's and student's personal progress. In this system, the assessment is designed by the subject teacher; it provides a platform for teachers to use a broader range of assessment methods in assessing students' abilities. Teachers do not limit the assessment to the traditional test method. In such cases, role-play, project work, presentation and other methods were used in the classroom during assessment. The respondents also pointed out that these assessments have no right or wrong answers, but the purpose was to evaluate how well the students were able to perform based on the learning outcomes. Indirectly, it encouraged teachers and students to develop their creativity and develop their talent. In addition, it also encouraged students to develop their thinking and analytical skills.

They can give many different answers, there are no wrong answers as long as they can give logical answers...we cannot limit their abilities, such as creativity ability. We cannot deny their ideas but we can guide them based on what they think,...this system emphasized on individual performance, ... no student can be left out (Mr. Chan)

Besides students, teachers also have shown personal progress by using various teaching approach to improve their teaching skills. Ms. Tan, mentioned that she has been using different methods to assess her students:

It could be any kind of format. Sometimes it is quizzes, sometimes it is acting, role-playing, sometimes it can be a short reading comprehension; many kinds of assessment can be done...sometimes I use real objects, ...I want them to speak out loud, then I want them to write... The answers are not limited, it is free and they can write anything (Ms Tan)

Ms. Tan also reflected that she has improved in her teaching skills:

I can see that I have improved in my teaching, I learned to use other teaching approaches that I have not used before... and it is very effective(Ms Tan)

Ms. Loh showed the improvement in her teaching skills by not limiting her questions to the text. She preferred to let students express their own experience in the speaking test. She said:

We need to let the students become familiar with different types of performances...to ensure students are able to achieve the goal...they should be able to express their feeling and ideas related to the real world... this system is aimed to produce a holistic individual and to encourage individual performance, we can already see a positive sign towards this aim. (Ms. Loh)

\subsection{Developed Positive Attitudes}

In primary language subjects, the curriculum focuses more on speaking than writing. Therefore students have more chances to practice their speaking skills through daily activities, for example role-playing and discussion. As a result, students are more out-spoken and less shy than they were in the old system. They have shown increased confidence in communicating with people and can do so politely and effectively. They also like to contribute ideas during discussion or in class activities, showing their commitment to learning. The teachers feel that this assessment system has reduced the pressure of exams and that the students now are happier, and therefore enjoy learning more.

Ms. Tan observed that her students have developed positive attitudes towards learning and assessment. They enjoy learning in her class:

To them, learning is fun, learning is not for the exam. They have no pressure. I can see that they are more confident, more proactive, and most importantly their attitude towards learning is different (Ms. Tan) 
Similarly, Ms. Loh also commented that her students looked happier than their elder siblings who were stillin the old system where they have to take exams.

\subsection{Enhance Collaborative Skills}

The activities, such as group work, role-play and practical work, not only give immediate feedback to teachers about students' progress, it has also encouraged the students to collaborate with their peers. They enjoy sharing ideas, discussing and solving problems together, and working towards the learning outcomes because this system has reduced the unhealthy or unnecessary competition among students. Some respondents also realized that they have improved their collaboration skills with their colleagues.

Before, the students were competing with each other because they wanted to get higher marks; now, since this assessment has no marks, there is less comparison and that encourages them to work together (Ms. Loh)

Ms. Loh said that under school-based assessment, both teachers and students need continuous collaboration. The need to collaborate in order to succeed heightens and further develops the collaborative skill required.

\section{... because the system is still new, I think it needs continuous effort from both teachers and students to work together (Ms. Loh)}

Ms. Tan claimed that the aim of grouping her students in a small group is to develop their collaboration skills.

We have grouped the students into smaller groups...so the stronger student will help teach the weaker. We also hope that they will learn to collaborate in doing so. (Ms. Tan)

\subsection{Promotes Creative Teaching and Learning Activities}

Though the teachers felt overwhelmed with their workloads, they managed to express positive perspectives on the effectiveness of this assessment system. Under this assessment system, teachers must use different assessment methods to assess students' learning outcomes. Teachers also use different teaching methods to ensure the effectiveness of the learning. Sometimes they use colorful pictures or real objects to stimulate students' thinking; sometimes they play games such as board games, bingo or scrabble to increase students' vocabulary, and they also give them worksheets for practice.

On the other hand, under the SBA's goal, which is "no one will be left out", they have to monitor every student's progress everyday to ensure the effectiveness of every lesson.

I really have to monitor every student's progress, have to check if s/he has grasped the skill, how much has s/he learned, what has s/he learned, what can s/he perform. So, every day I have to think of how I should teach, what strategies I should use so that they can learn a lot and not feel bored...we are like 'magicians', trying to change our teaching strategies every day to attract them (Ms. Tan)

I have to surf the internet to get ideas, you know. Nowadays students are smarter than us teachers when it comes to using the internet, so I have to be better. There are many good ideas and I try using new approaches, the students like it too. When the students enjoy the lesson, they motivate me to be more creative in my teaching (MsLoh)

\section{Discussions}

The respondents in this study agreed that amidst the challenges, the SBA has its own strengths and advantages that benefits them and their students alike. What they appreciate most of all is the move from an exam-oriented culture to a more relaxed and exam-free environment, especially to the Year I students. The students are happier, have more confidence and learn better because they do not have tests or exams to worry about. The students can even communicate better and be better team players when working as a group.

All these findings support the findings of the Hong Kong SBA Consultancy Team (2006) regarding the benefits of the SBA and validate the studies done by Chan, Sidhu, and, Md. Yunus (2006). The fact that teachers also benefit from SBA is in line with Brown (2001). However, this would only hold true if teachers regard the change positively and undertake the 'teething troubles' to push them to strive, thus turning the problems into challenges to be met.

The fact that these teachers find that the SBA promotes creative teaching and learning activities defies Adi (2006), who points out that most Malaysian teachers are far from ready to implement the SBA in their classroom. He feels that teachers have yet to understand the concept of SBA and thus lack the know-how to develop the assessment tasks, which will further lead to the validity of the school-based assessment. Though some teachers may fall under Adi's criticism, yet there are still more teachers out there who do not conform and are willing to 
struggle in ensuring that the policy holds. Of course subject matter, attitudes and sheer perseverance underlie the perceptions of these respondents, amongst other factors, which then might produce a different finding.

Good assessments are those that focus on students and their learning (Mitchell, 1992; Majid, 2011). Meaning, implementation of the SBA requires a set of procedures, which apply the minimum professional requirements to all teachers and personnel involved in the process of SBA. All teachers in this study admit that there were glitches or 'teething troubles,' mostly in preparing the instruments and in finding ways to embed the assessment into their classroom activities. Establishing a strong networking of professional personnel within and between schools could be a short-term solution to help these teachers. Furthermore, the education district offices should also move toward the establishment of a network of professional trainers to help implementers at the school level. Indirectly, this opens up opportunities for further research. More in-depth and comprehensive investigations that focus on the problems and challenges faced by the implementers found in the student feedback are deemed necessary.

\section{Conclusion}

In conclusion, this study shows that the teachers have the basic understanding of the characteristics of SBA in primary school. This study shows that SBA has benefited both teachers and students; the lively teaching approaches have impacted students' learning positively, and this has been reflected in the students' performing at a high standard in the school-based assessment. The limitation of this study is that the findings are only based on the perception of three respondents teaching the Chinese language to Year 1 students. However, these findings are significant within its limitations and are strongly supported by the documents collected - students' worksheet, students' marks and classroom videos. Thus, it is pertinent that this study be followed up with other subjects as well, using both the qualitative and quantitative methods. The feedbacks would certainly benefit academicians, stakeholders and policy makers in ensuring a smooth and successful SBA implementation in all schools.

\section{References}

AACU. (2011). The LEAP Vision for Learning Outcomes, Practices, impact, and employers' Views. Retrieved October 30, 2012, from http://www.aacu.org/leap/documents/leapvision_summary.pdf

Brown, G. T. L. (2001). School based assessment methods: Development and implementation. Journal of Assessment Paradigms, 1(1), 30-32.

Chan. Y. F., Sihdu, G. K., \& Md. Yunus, M. R. (2006). The knowledge and best practices of secondary school ESL teachers in school-based assessment. University Teknology Mara. Retrieved June 20, 2012, from http://eprints.ptar.uitm.edu.my/3181/1/LP_CHAN_YUEN_FOOK_06_24.pdf

Chapman, K. (2010). Ensuring Standards are Kept. The Star. Retrieved June 4, 2012, from http://thestar.com.my/education/story.asp?sec=education\&file=/2010/7/4/education/6589510

Davison, C. (2007). Views from the Chalk face: English Language SBA in Hong Kong. Language Assessment Quarterly, 4(1), 37-68.

Dietel, R. J., Herman, J. L., \& Knuth, R. A. (1991). What does research say about assessment? North Central Regional Educational Laboratory.

Kerr-Phillips, F. (2007). School based assessment: The need, the reality, the future. A perspective from the Independent Examinations Board of South Africa. Retrieved October 1, 2012, from http://www.iaea.info/documents/paper 1162d20227.pdf

Majid, F. A. (2011). SBA in Malaysian Schools: The concern of the English Teachers.US-China Education Review, 8(10).

Mansor, A. N., Wong, K. E., Rasul, M. S., Hamzah, M. I., \& Hamid, A. H. (2012). Effective Classroom Management. International Education Studies, 5(5), 35-42. http://dx.doi.org/10.5539/ies.v5n5p35

Mitchell, R. (1992). Testing for learning: How new approaches to evaluation can improve American schools. New York: The Free Press

MOE. (2012). Implementation of SBA for improvement of UPSR and PMR. Ministry of Education Malaysia.

SBA Consultancy Team. (2005). HKCEE English examination: Introduction to the SBA component. Hong Kong. Retrieved June 4, 2012, from http://www.hkeaa.edu.hk/DocLibrary/SBA/CE-Eng-07IntroBook let-0610.pdf

Tuah, A. B. (2006). Improving the quality of primary education in Malaysia through curriculum innovation: Some current issues on assessment of students' performance and achievement. Proceedings $3^{\text {rd }}$ International 
Conference on Measurement and Evaluation in Education (ICMEE), pp. 16-26. Penang: University Science of Malaysia.

Yong, H. T., \& Lim, C. S. (2008). Implementing School-Based Assessment: The Mathematical Thinking Assessment (MATA) Framework. Buku Koleksi Bahan Seminar Inovasi Pedagogi IPBL. 